\title{
Peran Orangtua dalam Memotivasi Belajar Peserta Didik di Masa Pembelajaran Daring
}

\author{
Dea Mustika ${ }^{1 *}$ \\ ${ }^{1}$ Universitas Islam Riau, Pekanbaru, Indonesia \\ *Coresponding Author: deamustika@edu.uir.ac.id \\ Dikirim: 09-12-2021; Direvisi: 10-12-2021; Diterima: 11-12-2021
}

\begin{abstract}
Abstrak: Tujuan penelitian adalah untuk mengetahui peran orangtua dalam memotivasi belajar peserta didik di masa pembelajaran daring. Penelitian ini merupakan penelitian kualititatif yang bersifat study kasus. Sumber data melibatkan tiga orang tua dan tiga orang peserta didik. Teknik pengumpulan data berupa wawancara, observasi dan dokumentasi. Keabsahan data diuji menggunakan triangulasi teknik dan triangulasi sumber. Analisis data menggunakan teknik Miles Huberman yang meliputi pada tahap reduksi data, penyajian data dan penarikan kesimpulan. Hasil penelitian menyimpulkan bahwa di masa pembelajaran daring orang tua berperan sebagai pembimbing yang mendampingi dan membantu mengarahkan peserta didik jika mengalami kesulitan dalam pembelajaran. Berperan sebagai fasilitator dengan menyediakan fasilitas belajar sesuai kebutuhan peserta didik selama pembelajaran daring. Berperan sebagai motivator dengan memberi dukungan berupa pujian dan hadiah pada peserta didik. Walaupun dalam pelaksanaan perannya masih terdapat hambatan tetapi peran yang telah dijalankan orang tua menunjukkan kepedulian orang tua terhadap pendidikan bagi peserta didik.
\end{abstract}

Kata Kunci: peran orang tua; motivasi belajar; pembelajaran daring

Abstract: The purpose of the study was to determine the role of parents in motivating students' learning during the online learning period. This research is a qualitative research which is a case study. The data source involved three parents and three students. Data collection techniques in the form of interviews, observation and documentation. The validity of the data was tested using technical triangulation and source triangulation. Data analysis used the Miles Huberman technique which included data reduction, data presentation and conclusion drawing. The results of the study concluded that during the online learning period, parents act as mentors who accompany and help direct students if they experience difficulties in learning. Act as a facilitator by providing learning facilities according to the needs of students during online learning. Act as a motivator by providing support in the form of praise and gifts to students. Although in the implementation of its role there are still obstacles but the role that has been carried out by parents shows parents' concern for education for students..

Keywords: the role of parents; learning motivation; online learning

\section{PENDAHULUAN}

Penyebaran virus covid-19 di Indonesia dimulai sejak tahun 2020 dan menyebar pada keseluruhan provinsi di Indonesia dengan sangat cepat. Cara terbaik yang disarankan agar virus tidak semakin menyebar adalah dengan cara menghindari penyebab penularan virus covid-19. Ini menjadi dasar bagi pemerintah melalui Kementerian Kesehatan sepakat untuk menerapkan protokol kesehatan dengan melakukan pembatasan terhadap interasi fisik (phsysical distancing) dan sosial (social distancing) (Novalia et al., 2021). Menteri Pendidikan dan Kebudayaan 
memberi tanggapan terhadap himbauan tersebut dengan mengeluarkan Surat Edaran Nomor 3 Tahun 2020. Pada surat edaran tercantum tujuh point penting, meliputi 1) himbauan untuk menunda penyelenggaraan acara yang mengundang kerumunan; 2) pejabat pimpinan tinggi madya, pimpinan tinggi pratama dan pimpinan unit lain bertanggung jawab terhadap pencegahan virus covid-19;3) mewajibkan pimpinan dan pegawai untuk bekerja dari rumah; 4) pimpinan dan pegawai yang mempunyai keluhan kesehatan diwajibkan istirahat di rumah; 5) pegawai kemendikbud menggunakan transportasi umum untuk datang ke kantor; 6) pengelola sistem persuratan adaan dokumentasi elektronik harus menjaga sistem dengan baik agar dapat digunakan untuk bekerja jarak jauh; 7) Kepala pusat data dan informasi berkoordinasi dengan biro umum dan pengadaan barang dan jasa untuk menyiapkan sarana dan prasaran serta tanda tangan elektronik (Makarim, 2020).

Menanggapi surat edaran tersebut, maka sekolah-sekolah pun mulai melakukan pembelajaran dari rumah. Pembelajaran yang biasanya dilakukan dengan cara langung bertatap muka di dalam kelas, diinstruksikan untuk diberhentikan sementara dengan maksud memutus mata rantai virus covid19. Agar pembelajaran tetap dapat berlangsung, maka pendidik pun berupaya untuk melaksanakan pembelajaran secara dalam jaringan atau lebih dikenal dengan istilah pembelajaran daring. Pendidik berkoordinasi dengan orang tua peserta didik untuk memberikan materi pembelajaran selama peserta didik belajar dari rumah.

Orang tua adalah bagian utama dari keluarga yang mempunyai peran penting dalam keberlangsungan pendidikan peserta didik. Orang tua berkewajiban menjaga, mendidik, dan membimbing anak sebagai peserta didik untuk mendapatkan pendidikan formal hingga mencapai kesuksesan (Ginanjar, 2017). Penelitian yang dilakukan (Hero \& Sni, 2018) menyatakan bahwa peran orang tua dapat berpengaruh dalam menentukan prestasi belajar peserta didik. Karakteristik dari orang tua juga dapat mempengaruhi kecakapan orang tua dalam menjalankan peran sebagai orang tua. Beberapa hal yang mempengaruhi pola asuh orang tua seperti lingkungan sekitar, budaya, dan pendidikan orang tua (Dewi \& Khotimah, 2020). Peserta didik yang tidak mendapat bimbingan dari orang tua dapat menyebakan peserta didik menjadi sulit untuk mencapai keberhasilan dalam belajar. Perhatian orang tua mampu membuat peserta didik menjadi giat dan lebih termotivasi dalam belajar.

Motivasi belajar dapat diartikan sebagai daya penggerak yang bersumber dalam diri peserta didik (Masni, 2015). Motivasi belajar memunculkan keinginan peserta didik untuk mengetahui lebih banyak tentang suatu konsep pengetahuan sehingga tujuan pembelajaran yang diharapkan dapat tercapai. Peserta didik yang mempunyai motivasi belajar yang tinggi maka juga akan memiliki prestasi belajar yang tinggi. Sebaliknya, peserta didik dengan motivasi belajar yang rendah akan memiliki prestasi belajar yang juga rendah (Jemudin et al., 2019). Tinggi dan rendahnya motivasi belajar peserta didik dapat diamati dari semangat yang ditunjukkan dalam belajar. Terdapat beberapa peran orang tua dalam kegiatan belajar peserta didik seperti menunjukan perhatian secara fisik maupun psikis, memahami kesulitan yang dialami peserta didik serta membantu memberikan solusi serta menyediakan fasilitas belajar yang mencukupi kebutuhan peserta didik (Yulianingsih \& Nugroho, 2021).

Dapat dicermati bahwasanya orang tua mempunyai peran yang teramat penting dalam pendidikan peserta didik, terutama pada saat diterapkannya pembelajaran 
daring. Orang tua harus lebih aktif mendampingi peserta didik selama belajar di rumah. Pendampingan dari orang tua diharapkan dapat meningkatkan motivasi belajar peserta didik. Wawancara yang peneliti lakukan bersama dengan salah seorang guru kelas V SDI Plus YLPI Pekanbaru menemukan informasi bahwa guru mengalami beberapa permasalahan dalam pembelajaran daring, salah satunya mengenai susahnya memunculkan motivasi belajar peserta didik selama belajar di rumah. Walaupun guru sudah berkoordinasi dengan orang tua tapi pada nyatanya selama pembelajaran daring guru masih menemukan beberapa orang peserta didik yang mengumpulkan tugas hasil dari menyalin atau copy paste pencarian diinternet. Wawancara dengan salah seorang wali orang tua peserta didik juga mendapatkan informasi bahwa orang tua kendala yang dihadapi orang tua dalam mendampingi proses belajar peserta didik selama di rumah adalah peserta didik yang terkadang sulit untuk diminta mengikuti pembelajaran. Peserta didik cepat jenuh dan kehilangan konsentrasi hingga kemudian memilih lebih asik bermain handphone. Sejalan dengan penelitian yang dilakukan oleh (Anggraeni et al., 2021) pada nyatanya peran orang tua dalam pembelajaran daring masihlah menunjukkan kendala seperti orang tua yang kesulitan mendampingi peserta didik belajar dikarenakan kurang memahami materi ataupun orang tua yang tidak bisa mendampingi peserta didik belajar secara maksimal karena harus bekerja.

Berdasarkan permasalahan yang telah diuraikan, maka perlu dilakukan kajian yang mendalam berkenaan dengan peran orang tua dalam memotivasi belajar peserta didik di masa pembelajaran daring. Rumusan masalah dalam penelitian ini adalah 1) bagaimana peran orang tua dalam memotivasi belajar peserta didik di masa pembelajaran daring? dan 2) apa saja hambatan yang dialami orang tua dalam memotivasi belajar peserta didik di masa pembelajaran daring?

\section{KAJIAN TEORI}

\section{Hakikat Peran Orang Tua}

Orang tua merupakan bagian dari keluarga yang keberadaannya sangat dibutuhkan untuk memberi bimbingan dan menyediakan kelengkapan fasilitas bagi peserta didik. Orang tua mempunyai peran yang besar sejak anak lahir hingga tumbuh besar. Tanggung jawab orang tualah untuk melindungi dan memelihara kelangsungan hidup peserta didik. Orang tua merupakan pendidik pertama di rumah dan pihak yang pertama kali berinteraksi dengan peserta didik. Dapat dikatakan bahwa orang tua merupakan guru pertama yang dikenal oleh peserta didik.

Orang tua mempunyai peran yang besar semenjak peserta didik lahir hingga tumbuh besar dengan merawat, menjaga, dan memelihara kelangsungan hidup anaknya (Tarmizi \& Sulastri, 2017). Peran dapat diartikan sebagai pola perilaku atau perbuatan yang menjadi ciri atau kedudukan seeseorang. Peran orang tua adalah bagian terbesar dari pendidikan peserta didik. Peran tersebut dapat direalisasikan dalam bentuk hubungan langsung yang dapat diekspresikan dalam bentuk dukungan pada peserta didik.

Menurut Tan dalam (Pantan \& Benyamin, 2020) terdapat tiga peran utama orang tua terhadap anak sebagai seorang peserta didik yaitu :

1. Orang tua sebagai fasilitator artinya orang tua menyediakan fasilitas belajar peserta didi. Fasilita belajar yang dimaksudkan seperti buku, alat tulis, komputer atau ruangan belajar yang layak dan nyaman. 
2. Orang tua sebagai motivator, artinya orang tua memberikan dukungan belajar kepada peserta didik. Dukungan tidak hanya berupa kalimat pujian tetapi dapat juga dengan memberikan hadiah atau pengertian terhadap kesulitan belajar yang peserta didik alami.

3. Orang tua sebagai pembimbing, artinya orang tua mendampingi peserta didik dalam pelaksanaan pembelajaran. Memahami kesulitan yang peserta yang didik alami serta memberikan solusi atau bantuan.

Dapat disimpulkan bahwa peran orang tua sangat penting, orang tua merupakan guru pertama yang memberi pendidikan dan pengajaran pada peserta didik. Orang tua berperan dalam membantu peserta didik menggali potensi yang dipunyai serta menjadi sumber semangat peserta didik untuk dapat belajar lebih giat lagi.

\section{Hakikat Motivasi Belajar}

Motivasi adalah gejala psikologis yang muncul dalam bentuk tindakan demi mencapai tujuan tertentu (Rois, 2019). Motivasi juga dapat dikatakan sebagai rangkaian usaha untuk memberikan situasi tertentu agar seseorang mempunyai keinginan untuk melakukan sesuatu (Sardiman, 2018). Motivasi diperlukan dalam penyelesaian masalah kehidupan tak terkecuali dalam pembelajaran.

Motivasi belajar merupakan kecenderungan peserta didik untuk belajar demi mencapai prestasi dan hasil belajar yang optimal (Rahman, 2021). Fungsi mottivasi belajar dijelaskan oleh (Wahidin, 2019) sebagai berikut :

1. Sebagai kekuatan artinya motivasi belajar dapat berfungsi sebagai pendorong timbulnya keinginan untuk belajar

2. Sebagai pengarah, artinya motivasi belajar dapat membantu mengarahkan perbuatan belajar untk pencapaian tujuan yang diharapkan

3. Sebagai penggerak, artinya motivasi belajar menjadi penentu cepat atau lambatnya suatu perbuatan tergantung pada seberapa besar motivasi yang dimiliki.

(Sardiman, 2018) juga menyatakan terdapat dua jenis motivasi belajar yaitu 1) Motivasi intrinsik yaitu motivasi yang berasal dari dalam diri peserta didik sendiri untuk melakukan sesuatu kegiatan belajar demi mencapai tujuan belajar tertentu dan 2) Motivasi ekstrinsik yaitu motivasi yang berasal dari luar diri peserta didik seperti pengaruh lingkungan sekitar atau dukungan dari orang tua. Munculnya motivasi belajar juga tak lepas dari faktor-faktor yang mempengaruhi. Beberapa faktor yang mempengaruhi motivasi belajar dapat berupa cita-cita atau aspirasi peserta didik, kemampuan peserta didik, kondisi peserta didik, dan kondisi lingkungan peserta didik (Moslem \& Komaro, 2019)

Motivasi belajar yang berasal dari dorongan eksternal atau internal pada dasarnya mengacu pada indikator yang mendukung. Indikator motivasi belajar dikemukakan oleh Uno dalam (Fitriyani et al., 2020) yang meliputi pada :

1. Adanya kemauan untuk berhasil. Kemauan untuk berhasil biasanya diistilahkan dengan motif prestasi yaitu motif untuk melakukan suatu tugas secara tuntas.

2. Adanya dorongan untuk belajar. Dorongan ini tampak melalui kegiatan belajar yang tekun agar terhindar dari kegagalan.

3. Adanya harapan masa depan. Harapan didasari oleh keyakinan pada diri peserta didik bahwa kesungguhan belajar yang dilakukan dapat 
4. Adanya penghargaan dalam belajar. Penghargaan dapat berupa pernyataan verbal sebagai bentuk pengakuan nyata terhapda keberhasilan belajar yang telah peserta didik capai.

5. Adanya kegiatan yang menarik dalam belajar. Kemenarikan dalam belajar ditandai dengan proses belajar yang terasa bermakna sehingga mudah diingat dan dipahami peserta didik.

6. Adanya lingkungan belajar yang kondusif. Lingkungan kondusif menjadi bagian penting dalam kenyamanan peserta didik selama kegiatan pembelajaran karena lingkungan membantu peserta didik untuk dapat belajar dengan penuh konsentrasi.

Dapat disimpulkan bahwa motivasi belajar merupakan bagian penting yang harus dimiliki oleh peserta didik agar dapat mencapai keberhasilan dalam belajar. Motivasi belajar dipengaruhi oleh faktor-faktor baik faktor eksternal maupun faktor internal.

\section{METODE PENELITIAN}

Metode penelitian yang digunakan adalah penelitian kualitatif deskripstif. Penelitian kualitatif merupakan jenis penelitian yang temuannya tidak diperoleh dari perhitungan statistik atau bentuk cara lain yang menggunakan ukuran angka. Penelitian dilaksanakan di SD Islam Plus YLPI Pekanbaru.

Sumber data dalam penelitian ini terdiri dari sumber data primer dan sumber data sekunder. Sumber data primer melibatkan 3 orang tua yaitu Ibu TR, Ibu YS dan Bapak OW serta 3 orang peserta didik yaitu AT, R dan NN. Sedangkan sumber data sekunder diperoleh dari keterangan guru kelas berupa buku nilai utuk melihat hasil dari motivasi belajar peserta didik SD Islam Plus YLPI Pekanbaru.

Tekhnik pengumpulan data dalam penelitian berupa tekhnik wawancara dengan instrumen lembar pedoman wawancara, tekhnik observasi dengan instrumen lembar observasi dan dokumentasi dengan instrumen telaah dokumen. Keabsahan data dalam penelitian diuji menggunakan triangulasi tekhnik dan triangulasi sumber. Triangulasi teknik berupa pengujian data dari sumber data dengan menggunakan teknik yang berbeda, sedangkan triangulasi sumber berupa pengujian kebenaran data dengan membandingkan data pada sumber yang berbeda.

Tekhnik analisis data dalam penelitian menggunakan tekhnik Miles dan Huberman. Tiga tahapan teknik analisis data diuraikan sebagai berikut :

1. Analisis data dilakukan dengan cara mengumpulkan data menggunakan teknik yang telah ditentukan pada sumber data. Data selanjutnya dikelompokkan untuk direduksi.

2. Reduksi data dilakukan dengan cara memilah data yang telah didapat untuk kemudian disesuaikan dengan indikator penelitian yang telah ditentukan. Data yang tidak sesuai selanjutnya dibuang atau tidak digunakan.

3. Penyajian data dilakukan dengan menjabarkan data yang telah dikelompokkan menjadi uraian deskriptif hingga dapat ditarik menjadi kesimpulan terkait dengan peran guru dalam memotivasi belajar peserta didik. 


\section{HASIL DAN PEMBAHASAN}

Peran orang tua dalam memotivasi peserta didik dalam penelitian ini ditinjau meliputi pada tiga indikator peran yaitu 1) peran orang tua sebagai pembimbing; 2) peran orang tua sebagai fasilitator; dan 3) peran orang tua sebagai motivator. Berikut diuraikan hasil olah data pada penelitian ini.

\section{Peran Orang Tua sebagai Pembimbing}

Sebagai seorang pembimbing orang tua berupaya memberikan bimbingan selama peserta didik belajar di rumah. Bimbingan yang diberikan orang tua meliputi pada pendampingan peserta didik selama belajar daring dan membantu menyelesaikan kesulitan belajar yang peserta didik alami. Hasil wawancara dengan orang tua peserta didik diketahui bahwa orang tua mengakui tidak dapat secara maksimal mendampingi siswa selama belajar di rumah. Hal ini dikarenakan kondisi orang tua yang juga bekerja. Walaupun ibu YS berprofesi sebagai ibu rumah tangga, tetapi ibu YS mempunyai dua orang anak yang masih berumur balita sehingga tidak bisa mendampingi NN belajar sepenuhnya. Namun untuk memaksimalkan jam belajar peserta didik, orang tua berupaya untuk membantu peserta didik menyusun jadwal tugas dengan mengisi buku harian yang sekolah berikan. Dalam membantu peserta didik mengatasi kesulitan belajar, orang tua upayakan dengan mengecek ulang tugas peserta didik sebelum dikumpulkan pada guru kelas. Selain itu, Bapak OW secara khusus memberi peserta didik kursus private agar lebih optimal dalam belajar. Hambatan yang orang tua hadapi dalam menjalankan perannya sebagai pembimbing adalah saat diminta mendampingi peserta didik untuk belajar secara penuh tidak dapat dilakukan oleh orang tua. Alasannya karena orang tua mempunyai pekerjaan lain sehingga tidak memungkinkan untuk terus mendampingi peserta didik mengikuti proses pembelajaran.

Wawancara yang peneliti lakukan bersama peserta didik juga menemukan hasil yang sejalan bahwa orang tua telah membantu mendampingi peserta didik dalam belajar tetapi memang tidak secara penuh. Orang tua lebih banyak mendampingi peserta didik dalam pembuatan tugas dan terkadang juga membantu mengarahkan peserta didik menyelesaikan tugas yang kurang dipahami. Peserta didik memahami bahwa orang tua tidak bisa mendampingi proses belajar secara utuh dikarenakan orang tua yang harus melakukan pekerjaan lain. Saat peneliti melakukan observasi proses pembelajaran yang dilakukan peserta didik selama belajar di rumah, peneliti mengamati bahwa orang tua hanya mengawasi kegiatan belajar peserta didik dari jauh. Orang tua mengawasi dengan tetap melakukan pekerjaan lain seperti mengikuti seminar online dan mengerjakan pekerjaan rumah tangga lainnya. Akan tetapi, ketika peserta didik mengalami kesulitan dalam menyelesaikan tugas yang guru berikan maka masing-masing orang tua memberikan tanggapan yang cukup cepat untuk membantu menyelesaikan kesulitan yang peserta didik alami.

Orang tua sebagai pembimbing dapat diartikan bahwa orang tua membantu peserta didik mencapai pengembangan dirinya secara optimal (Arsilawita et al., 2021). Sejalan dengan yang dijelaskan oleh Maimunawati \& Alif (2015) yang menyatakan bahwa sebagai pembimbing orang tua dapat berperan dengan membantu mengarahkan peserta didik jika mengalami kekurang pahaman dalam pembelajaran, membimbing peserta didik membuat jadwal tugas yang teratur dan mengarahkan peserta didik untuk mengerjakan atau menyelesaikan pekerjaan rumah tepat waktu. Dalam penelitian ini, peran orang tua sebagai pembimbing difokuskan pada 
bimbingan atau pengawasan yang orang tua berikan selama peserta didik belajar secara daring.

Menurut Ana (2021) orang tua sebagai pembimbing berperan dalam membimbing keterampilan dasar peserta didik, seperti patuh pada aturan atau melakukan pembiasaan yang baik namun selanjutnya peran tersebut dapat semakin meluas misalnya sebagai pemndamping peserta didik dalam pendidikan akademik. Pada penelitian ini orang tua telah berupaya menjalankan perannya sebagai pembimbing bagi peserta didik, walaupun peran tersebut masih mengalami hambatan karena orang tua yang tidak bisa mendampingi peserta didik belajar secara utuh namun orang tua tetap berusaha membantu peserta didik jika mengalami kesulitan dalam pembelajaran.

\section{Peran Orang Tua sebagai Fasilitator}

Sebagai seorang fasilitator orang tua berupaya memfasilitasi kebutuhan belajar peserta didik selama belajar di rumah. Fasilitas yang orang tua sediakan selama masa pembelajaran daring meliputi pada gadget/smartphone, jaringan internet, buku dan alat tulis. Hasil wawancara dengan orang tua peserta didik diketahui bahwa orang tua pada dasarnya telah berupaya memberikan fasilitas yang peserta didik butuhkan selama masa pembelajaran daring. Untuk kebutuhan gadget/smartphone Ibu TR dan dan Ibu YS memfasilitasi peserta didik dengan smartphone yang orang tua miliki, sedangkan Bapak OW memutuskan untuk membelikan smartphone yang khusus digunakan untuk pembelajaran daring. Hambatan yang terjadi adalah ketika orang tua yang berbagi smartphone dengan peserta didik sedang menggunakan smartphone untuk bekerja sehingga peserta didik harus berhenti mengikuti pembelajaran sebentar dan menunggu hingga orang tua selesai dengan urusan pekerjaannya. Kebutuhan jaringan internet juga dipenuhi oleh orang tua, selain memanfaatkan internet kuota belajar yang tersedia, orang tua juga membelikan paket internet khusus untuk peserta didik. Bapak OW bahkan memasang wifi yang dikhususkan untuk peserta didik gunakan belajar. Hambatan yang terjadi adalah saat kuota internet habis ditengah pembelajaran peserta didik, karena menurut orang tua terkadang guru mengharuskan peserta didik menyimak materi melalui tayangan youtube yang cukup menghabiskan kuota internet dengan cepat. Kebutuhan buku dan alat tulis juga telah dipersiapkan oleh orang tua dengan sebaik mungkin. Setiap orang tua menyediakan buku baik buku teks ataupun buku tulis seperti yang telah dihimbaukan oleh guru kelas. Dalam menyediakan buku dan alat tulis tidak ada hambatan yang orang tua rasakan karena di awal pembelajaran daring guru telah merincikan buku yang perlu disediakan oleh orang tua untuk peserta didik.

Hasil ini diperkuat dengan wawancara yang peneliti lakukan bersama peserta didik. Peserta didik membenarkan bahwa orang tua telah memfasilitasi mereka dengan menyediakan smartphone, jaringan internet, buku dan alat tulis. Sejalan dengan pendapat orang tua masing-masing, peserta didik mengakui bahwa walau fasilitas telah diberikan terkadang terdapat beberapa hambatan yang terjadi. Peserta didik yang menggunakan smartphone orang tua pernah sesekali terhenti mengikuti pembelajaran karena smartphone sedang dipakai oleh orang tua. Selain itu, peserta didik juga mengakui bahwa guru cukup sering memberikan materi melalui youtube sehingga kuota internet cepat habis. Untuk kebutuhan buku dan alat tulis, peserta 
didik beranggapan bahwa orang tua masing-masing telah menyediakan buku dan alat tulis yang cukup untuk mereka selama belajar dari rumah.

Fasilitas belajar merupakan salah satu yang mempengaruhi motivasi belajar peserta didik. Sejalan dengan penelitian yang dilakukan oleh Yugiswara et al. (2019) dalam menyediakan fasilitas belajar, orang tua haruslah memahami kebutuhan belajar peserta didik seperti ketersediaan ruang belajar, buku bacaan serta alat tulis. Sedangkan dalam penelitian ini karena memfokuskan pada pembelajaran daring maka ketersediaan belajar pun disesuaikan dengan kebutuhan belajar peserta didik di masa pembelajaran daring.

Menurut Siahaan \& Pramusinto (2018) fasilitas belajar dapat menentukan keberhasilan belajar peserta didik. Peserta didik yang belajar degan fasilitas belajar yang baik dan mencukupi maka dapat belajar dengan lancar teratur, sedangkan peserta didik yang belajar dengan fasilitas yang kurang maka akan mengalami kendala dalam pelaksanaan kegiatan pembelajaran. Dalam penelitian ini orang tua telah berupaya menjalankan perannya sebagai fasilitator dengan melengkapi fasilitas belajar yang peserta didik butuhkan. Kendala yang dihadapi orang tua sebagai fasilitator adalah dalam menyediakan smartphone khusus untuk peserta didik belajar daring serta kuota internet yang terkadang tidak mencukupi.

\section{Peran Orang Tua sebagai Motivator}

Sebagai seorang motivator orang tua berperan untuk memberikan dorongan belajar pada peserta didik. Dorongan belajar yang orang tua berikan dapat berupa pemberian pujian dan pemberian hadiah sebagai bentuk apresiasi atas keberhasilan peserta didik. Hasil wawancara dengan orang tua peserta didik didapatkan informasi bahwa orang tua cukup sering memberikan pujian kepada peserta didik. Kata pujian yang biasa dilontarkan oleh orang tua seperti "mantap", "hebat" dan "bagus". Hanya saja saat peserta didik mendapatkan hasil belajar yang cukup rendah, tidak semua orang tua memberikan pujian. Hanya Bapak OW yang konsisten mengatakan tetap memuji peserta didik walau memperoleh hasil belajar yang kurang sesuai. Hal ini dilakukan karena menurut Bapak OW peserta didik harus diberi selalu di apresiasi agar tetap bersemangat dalam mengikuti pembelajaran. Pemberian hadiah kepada peserta didik juga telah pernah dilakukan oleh orang tua. Hadiah orang tua berikan beragam dan biasanya dijanjikan mulai awal semester. Ini dikarenakan agar orang tua dan peserta didik mempunyai kesepakatan. Hadiah yang diberikan dicontohkan dengan membelikan makanan, kotak pensil, buku komik atau mainan yang peserta didik yang sukai. Hambatan yang orang tua hadapi sebagai motivator adalah saat memberikan pujian terkadang orang tua enggan memberi pujian saat peserta didik mendapatkan nilai belajar yang rendah. Jika peserta didik mendapat nilai rendah orang tua lebih cenderung memarahi dan mengancam membatalkan hadiah yang sudah dijanjikan.

Hasil wawancara dengan peserta didik mendapatkan informasi bahwa orang tua memuji saat peserta didik mendapat nilai yang bagus, tetapi saat peserta didik mendapat nilai yang kurang bagus orang tua cenderung marah dan mendiamkan. Peserta didik juga mengatakan bahwa orang tua juga pernah memberikan hadiah untuk peserta didik, hadiah yang diberikan tidak sering dan diberikan apabila peserta didik mendapat nilai belajar yang sesuai harapan orang tua. Hadiah yang pernah peserta didik terima seperti tas sekolah, alat tulis, mainan, makanan ataupun pergi diajak bermain ke tempat permainan. Hasil observasi yang peneliti lakukan ketika 
mengamati proses pembelajaran peserta didik selama di rumah, peneliti mengamati orang tua memberikan pujian berupa ucapan ketika guru menginformasikan nilai latihan peserta didik diperteuan sebelumnya apabila nilai tersebut bagus. Teramati Ibu TR karena peserta didik AT mendapatkan nilai yang cukup rendah tidak memberikan pujian dan hanya diam saja. Saat peneliti menelaah hasil belajar siswa melalui buku nilai yang guru miliki, peneliti menemukan bahwa peserta didik ratarata selalu mendapatkan nilai latihan yang cukup bagus dan sering di atas KKM.

Motivasi merupakan bentuk penghargaan yang orang tua berikan kepada peserta didik baik berupa kata-kata, hadiah ataupun hukuman. Sejalan dengan penelitian yang dilakukan oleh Wigih (2020) pemberian motivasi dari orang tua kepada peserta didik dapat berpengaruh terhadap prestasi belajar peserta didik, karena dengan motivasi tersebut maka peserta didik akan lebih bersemangat dalam belajar. Motivasi yang diberikan dapat berupa penghargaan, hadiah, bantuan belajar atau hukuman. Dalam penelitian ini motivasi difokuskan pada pemberian pujian dan pemberian hadiah karena ini merupakan bentuk motivasi yang paling mudah diamati selama pembelajaran daring.

Amseke (2018) juga menyatakan bahwa dukungan yang orang tua berikan dalam bentuk perhatian dan penghargaan dapat membuat peserta didik lebih antusias mengikuti kegiatan pembelajaran.Orang tua sebaiknya menghindari memberi dukungan dengan membantu menyelesaikan tugas peserta didik karena dapat membuat peserta didik menjadi lebih malas dan orang tua sebaiknya juga menghindari memberi respon negatif ketika peserta didik mendapat prestasi yang kurang bagus karena dapat mengurangi semangat belajar peserta didik. Pada penelitian ini orang tua telah menjalankan perannya sebagai motivator dengan memberi pujian dan juga hadiah. Hanya saja masih terdapat kendala dalam pemberian pujian yang masih sering diberikan hanya ketika peserta didik mendapat hasil belajar sesuai harapan orang tua.

Berdasarkan pada reduksi data penelitian maka dapat diketahui bahwa dalam memotivasi belajar peserta didik di masa pembelajaran daring orang tua telah berupaya menjalakan peran sebagai pembimbing, fasilitator dan motivator. Walaupun dalam setiap peran orang tua mengalami hambatan tetapi hambatan tersebut tidak menghilangkan kepedulian orang tua terhadap peserta didik. Karena pada nyatanya campur tangan orang tua dalam proses pendidikan yang peserta didik terima sangat diperlukan agar peserta didik menjadi pribadi yang lebih bersemangat dan bertanggung jawab.

Sejalan dengan yang dikemukakan oleh Chusna \& Utami (2020) kehadiran orang tua dalam proses pendidikan pada masa sekolah dasar mempunyai pengaruh yang cukup besar dibandingkan dengan usia peserta didik yang sudah lebih dewasa. Keterbatasan dalam penelitian ini adalah terbatasnya peran yang peneliti teliti karena terbatasnya waktu penelitian dilakukan. Harapannya dengan hasil penelitian ini dapat menjadi pedoman lebih lanjut untuk meneliti peran orang tua lainnya sehingga dapat membantu peserta didik meraih hasil belajar yang lebih maksimal.

\section{KESIMPULAN}

Peran orang tua dalam memotivasi belajar peserta di masa pembelajaran daring tampak dari peran sebagai pembimbing, fasilitator dan motivator. Orang tua telah berupaya mendampingi peserta didik, memenuhi kebutuhan peserta didik dalam 
pembelajaran serta mengawasi keterlaksanaan pembelajaran yang peserta didik lakukan. Saat menjalankan perannya orang tua masih mengalami beberapa hambatan, namun dengan terlaksananya peran ini telah menunjukkan kepedulian orang tua terhadap peserta didik. Orang tua memanglah harus terlibat dalam setiap kegiatan peserta didik terutama di masa-masa usia sekolah, karena pada masa ini peserta didik lebih mudah diarahkan. Dengan adanya kesadaran orang tua terhadap peran yang harus dimiliki maka dapat menjadikan peserta didik menjadi lebih bersemangat dalam mengikuti pembelajaran.

\section{DAFTAR PUSTAKA}

Amseke, F. V. (2018). Pengaruh Dukungan Sosial Orang Tua Terhadap Motivasi Berprestasi. Ciencias: Jurnal Penelitian Dan Pengemabangan Pendidikan, 1(1), 65-81.

Ana, R. F. R. (2021). Peran Orang Tua dalam Menumbuhkan Minat Belajar Siswa pada Pembelajaran Daring di SDN Kamulan 01 Kecamatan Talun Kabupaten Blitar. Jurnal Bidang Pendidikan Dasar, 5(2), 177-186. https://doi.org/10.21067/jbpd.v5i2.5773

Anggraeni, N., Fakhriyah, F., \& Ahsin, M. N. (2021). Peran Orang Tua sebagai Fasilitator Anak dalam Proses Pembelajaran Online di Rumah. Jurnal Ilmiah Pendidikan Dasar, VIII(2), 105-117. https://doi.org/10.30659/pendas.8.2.105117

Arsilawita, A., Suhaili, N., Mudjiran, M., \& ... (2021). Pengaruh Bimbingan Konseling dan Program Parenting untuk Meningkatkan Pemahaman Orangtua tentang Pentingnya Peran Orang Tua dalam Pendidikan. Jurnal Pendidikan ..., 5(1), 976-988. https://jptam.org/index.php/jptam/article/view/1058

Chusna, P. A., \& Utami, A. D. M. (2020). Dampak Pandemi Covid-19 terhadap Perang Orang Tua dan Guru dalam Meningkatkan Kualitas Pembelajaran Daring Anak Usia Sekolah Dasar. Jurnal Premiere, 2(1), 11-30.

Dewi, P. A. S. C., \& Khotimah, H. (2020). Pola Asuh Orang Tua pada Anak di Masa Pandemi Covid-19.

Fitriyani, Y., Fauzi, I., \& Sari, M. Z. (2020). Motivasi Belajar Mahasiswa Pada Pembelajaran Daring Selama Pandemik Covid-19. Profesi Pendidikan Dasar, 7(1), 121-132. https://doi.org/10.23917/ppd.v7i1.10973

Ginanjar, M. H. (2017). Keseimbangan Peran Orang Tua Dalam Pembentukan Karakter Anak. Edukasi Islami: Jurnal Pendidikan Islam, 2(03), 230-242. https://doi.org/http://dx.doi.org/10.30868/ei.v2i03.27

Hero, H., \& Sni, M. E. (2018). Peran Orang Tua Dalam Meningkatkan Motivasi Belajar Siswa Kelas V Di Sekolah Dasar Inpres Iligetang. JRPD (Jurnal Riset Pendidikan Dasar), 1(2), 129-139. https://doi.org/10.26618/jrpd.v1i2.1568

Jemudin, F. D. ., Makur, A. P., \& Ali, F. A. (2019). Hubungan Sikap Belajar Dan Motivasi Belajar Terhadap Prestasi Belajar Matematika Siswa Smpn 6 Langke Rembong. Journal of Honai Math, 2(1), 1-11. https://doi.org/https://doi.org/10.30862/jhm.v2i1.53 
Maimunawati, S., \& Alif, M. (2015). Peran Guru, Orang Tua, Metode dan Media Pembelajaran: Strategi KBM di Masa Pandemi Covid-19. Media Karya.

Makarim, N. A. (2020). Surat Edaran Menteri Pendidikan Dan Kebudayaan Republik Indonesia Tentang Pencegahan Corona Virus Disease (Covid-19) Pada Satuan Pendidikan. Surat Edaran Menteri Pendidikan Dan Kebudayaan Republik Indonesia Nomor 3 Tahun 2020, 3(1), 2. https://covid19.hukumonline.com/wpcontent/uploads/2020/04/surat_edaran_menteri_pendidikan_dan_kebudayaan_n omor_3_tahun_2020-2.pdf

Masni, H. (2015). Strategi Meningkatkan otivasi Belajar Mahasiswa. Dikdaya, 5(1), $34-45$.

Moslem, M. C., \& Komaro, M. (2019). Faktor-Faktor Yang Menyebabkan Rendahnya Motivasi Belajar Siswa Dalam Mata Pelajaran Aircraft Drawing Di Smk. Journal of Mechanical Engineering Education, 6(2), 258-265. https://doi.org/10.17509/jmee.v6i2.21803

Novalia, V., Siregar, S. R., \& Fathiah. (2021). Sosialisasi New Normal, Dampak Covid-19 dan Bakti Sosial; Hadapi New Normal dengan Strategi Pembelajaran Digital di Gampong Lhokcut, Kecamatan Sawang, Kabupaten Aceh Utara. Jurnal Pengabdian Masyarakat (Kesehatan), 3(1), 1-10.

Pantan, F., \& Benyamin, P. I. (2020). Peran Keluarga dalam Pendidikan Anak pada Masa Pandemi Covid-19. KHARISMATA: Jurnal Teologi Pantekosta, 3(1), 1324. https://doi.org/10.47167/kharis.v3i1.43

Rahman, A. (2021). Pengaruh Perhatian Orang Tua dan Motivasi Belajar terhadap Hasil Belajar pada Mata Pelajaran Sejarah Indonesia. Jurnal Pendidikan Indonesia, 2(2), 171-180.

Rois, N. (2019). Konsep Motivasi, Perilaku, dan Pengalaman Puncak Spiritual Manusia dalam Psikologi Islam. Jurnal Pendidikan Agama Islam Universitas Wahid Hasyim, 7(2), 184-198.

Sardiman. (2018). Interaksi dan Motivasi Belajar Mengajar. PT Raja Grafindo Persada.

Siahaan, C. D., \& Pramusinto, H. (2018). Pengaruh Disiplin Belajar, Lingkungan Sekolah, dan Fasilitas Belajar terhadap Hasil Belajar. Economic Education Analysis Journal, 7(1), 279-285.

Tarmizi, A., \& Sulastri. (2017). Peran Orang Tua Dalam Pendidikan Anak Usia Dini. Raudhatul Athfal: Jurnal Pendidikan Islam Anak Usia Dini, 1(October), 61-80. https://doi.org/https://doi.org/10.19109/ra.v1i1.1526

Wahidin. (2019). Peran Orang Tua dalam Menumbuhkan Motivasi Belajar Anak Sekolah Dasar. Pancar, 3(1), 232-245.

Wigih, K. (2020). Peran Orang Tua dalam Menumbuhkan Motivasi Belajar Siswa Mi Muhammadiyah Kaligondang Kecamatan Kaligondang Kabupaten Purbalingga. http://repository.iainpurwokerto.ac.id/id/eprint/7696

Yugiswara, A., Sukidin, S., \& Kartini, T. (2019). Pengaruh Fasilitas Belajar Terhadap Movasi Belajar Siswa Kelas Xi Ips Sma Negeri 1 Kraksaan 
Probolinggo Tahun 2018. JURNAL PENDIDIKAN EKONOMI: Jurnal Ilmiah Ilmu Pendidikan, Ilmu Ekonomi Dan Ilmu Sosial, 13(1), 101. https://doi.org/10.19184/jpe.v13i1.10427

Yulianingsih, W., \& Nugroho, R. (2021). Keterlibatan Orangtua dalam Pendampingan Belajar Anak selama Masa Pandemi Covid-19. Jurnal Obsesi: Jurnal Pendidikan Anak Usia Dini, 5(2), 1138-1150. https://doi.org/10.31004/obsesi.v5i2.740 